\title{
Effect of Curcumin (Curcuma longa) and Red Ginger (Zingiber officinale) on Hematology Values of Broilers
}

\author{
Maksudi Maksudi ${ }^{1}$, Fahmida Manin $^{1}$, Sri Wigati ${ }^{1}$, Anie Insulistyawati ${ }^{1}$, Nurbani Aziz ${ }^{1} \&$ Pudji Rahayu $^{1}$ \\ ${ }^{1}$ Department of Animal Health, Faculty of Animal Husbandry, Jambi University, Indonesia \\ Correspondence: Maksudi Maksudi, Department of Animal Health, Faculty of Animal Husbandry, Jambi \\ University, Indonesia. Tel: 62-822-8407-3448/62-877-2073-7557. E-mail: maksudi.unja@gmail.com
}

Received: June 2, 2020 Accepted: July 7, 2020 Online Published: December 4, 2020

\begin{abstract}
The purpose of this study was to determine the effect of supplemented curcumin (Curcuma longa) and red ginger (Zingiber officinale) on hematological values of broilers. Three hundred twenty one-day-old broilers were randomly distributed into 8 treatment groups with 4 replicates (pens) of 10 chicks each. The treatment diets were control groups (T01=basal diet and T02 =basal diet + bacitracin), and treatment diets supplemented with curcumin (C1, C2, and C3), and supplanted with ginger (Z1, Z2 and Z3). Results showed that PVCs and hemoglobin level of the chickens fed treatment diets increased significantly $(\mathrm{P}<0.05)$ compare to the control diets, and the erythrocytes of the chickens fed diet supplemented with ginger increased significantly $(\mathrm{P}<0.05)$ compared to the control in period I (21 days of age) but no significant differences in Period II (34 days of age). Furthermore, treatment diets had no effect on erythrocyte indices of MCHC and MCV (P>0.05). However, dietary inclusion of the addition of ginger significantly decreased $\mathrm{MCH}$ in period I $(\mathrm{P}<0.05)$, but no significant differences were observed in period II. Furthermore, the treatment diets had significantly lower leucocytes and heterophils/lymphocytes ratios $(\mathrm{P}<0.05)$ than the control diets, but no significant differences were investigated in the percentage of differential leucocytes of eosinophils and basophils. In conclusion, the use of curcumin and ginger up to the level of $1.5 \%$ indicated the potentcy of improving the general health status of broilers. They have been able to improve the hematological values, and reduce the stress level of the chickens.
\end{abstract}

Keywords: curcumin, ginger, hematology, erythrocytes, erythrocyte indices, leukocytes, differential leukocytes

\section{Introduction}

Prohibition of the use of synthetic antibiotics as growth promoters in the livestock industry has been imposed in Indonesia since 2018, although this ban has not been fully enforced. The Indonesian government's ban on the use of synthetic antibiotics is limited to their use in supplementation to animal feed. The synthetic antibiotics can still be used for therapeutic purposes with a maximum of 7 days use by prescription and veterinarian supervision (Rahmawati, 2018). This policy appears as a reaction to the potential for antibiotic resistance in livestock that was stimulated with AGP (antibiotics growth promoter). Some empirical evidences have been found, namely with the emergence of resistance of several types of pathogenic microorganisms and antibiotic residues in livestock due to the use of AGP that is not/less controlled. In comparison with other countries, the European Union in 2001 banned the use of several antibiotics as growth promoters in the livestock industry to increase its production, and then banned it totally in 2004. Furthermore, in 2010, the ban on the use of most types of synthetic antibiotics expanded to Asian countries, such as South Korea and Japan that prohibit the use of most synthetic antibiotics in livestock (Smith et al., 2011). Substitutes after a limited ban on the use of AGP are medicinal plants as natural AGP. In Indonesia, medicinal plants are traditionally processed into herbs for humans and livestock. Some medicinal plants, such as temu ireng (Curcuma aeruginosa), kencur (Kaempferia galanga), mengkudu (Morinda citrifolia), meniran (Phyllanthus niruri), temu lawak (Curcuma zanthorrhiza), sambiloto (Andrographis paniculata) and many more, including curcumin and ginger are often used to make these herbs. These medicinal plants contain active compounds as antiviral, antibacterial, anti-parasitic, and antioxidant or as immunomodulatory. Utilizing medicinal plants as livestock herbal medicine is an alternative medicine in livestock, if consumed regularly can improve the immune system of both livestock and humans, and do not leave residues (Saefudin et al., 1916). This fact shows that traditional medicinal plants can actually be used for health programs in livestock for maximum production purposes because of their abundant availabilities and low prices in markets. Ironically, some drugs or supplements made from medicinal plant ingredients have been widely available in pharmacies or drug stores, and they are usually for humans and rarely for animals. 
Therefore, the main problem is that although the beneficial effects of ginger and turmeric and others have been widely exploited in human nutrition, not much research has been done on their activities in livestock and in their use in livestock business. Some studies using medicinal plants in animals have actually been available, including research conducted by Godbole et al. (2018). The research found that curcumin at dose $400 \mathrm{mg} / \mathrm{kg}$ diet had ameliorative effect on altered hemato-biochemical profile in Escherichia coli induced broilers, and a research conducted by Liu et al. (2020) found that supplemental $150 \mathrm{mg} / \mathrm{kg}$ of curcumin improved immune function in lying hens under heat stress condition. However, Ginger powder at the used levels of up to $0.6 \%$ in another experiment did not yet show potency to be used as a growth promoter in broiler chicks (Hassan et al., 2019). The results of this study reinforce previous studies that supplementation of curcumin powder as much as $0.2 \%$ at hot ambient temperatures has been able to increase erythrocytes, PCV and life weight gain (Kusnadi and Rachmat, 2010). For this reason, the purpose of this study is to affect the use of curcumin (Curcuma longa) and red ginger (Zingiber officinale) in broiler chicken blood by looking at its hematological values. For this reason, the research that has been carried out was expected to be one of the basic considerations for more attention to the use of medicinal plants, especially ginger and curcumin as a substitute for AGP, especially for preventing diseases, instead for therapies.

\section{Materials and Methods}

The trial protocol was approved by the Ethical Clearance Committee, and it was performed following the Guidelines of Animal Use of the Faculty of Animal Husbandry, Jambi University, Jambi, Indonesia. Three hundred twenty one-day-old Cobb broilers were randomly distributed into 8 groups of treatments with 4 replicates (pens) of 10 chicks each. All chicks were reared on wire flooring pens $(1.0 \mathrm{~m} \times 1.0 \mathrm{~m})$ provided a 24 -h light program for the first week, and the rest of study study, daylight was used and replaced with 12-h lighting at night from incandescent bulbs.

Curcumin (Curcuma longa) and red ginger (Zingiber officinale) used in this study were purchased from traditional markets and prepared by being washed, sliced, dried, and grounded into powder using a flour machine. They were mixed with the basal diet with appropriate amount of each treatment, namely: T01 = control of the basal diet; T02 $=$ control of basal diet $+0.5 \mathrm{mg}$ bacitracin $/ \mathrm{kg}$ diet; $\mathrm{C} 1=$ basal diet $+0.75 \%$ curcumin; $\mathrm{C} 2=$ basal diet $+1.0 \%$ curcumin; $\mathrm{C} 3=$ basal diet $+1.5 \%$ curcumin; $\mathrm{Z1}=$ basal diet $+0.75 \%$ ginger; $\mathrm{Z2}=$ basal diet $+1.0 \%$; $\mathrm{Z} 3=$ basal $\operatorname{diet}+1.5 \%$ ginger. The basal diet was formulated to meet the energy and protein requirements for broiler chicken growth, containing 3,200 kcal ME and 23\% CP/ $\mathrm{kg}$ feed for period I (21 days of age), and 3,200 kcal ME and 20\% $\mathrm{CP} / \mathrm{kg}$ feed for period II (34 days of age; NRC, 1994). The diets and water were given ad libitum to the chickens during the trials in periods I and II.

Blood samples were obtained from chickens taken randomly from each unit/pen of the experiment through the slaughtering procedure that was carried out at the age of 21 days for period I and age 34 days for period II. Blood samples are collected using glass tubes that have been added by anti-coagulant EDTA, and then the blood samples were stored in a cooler box and transported to a laboratory for hematology examination. Testing of packed cell volume (PCV) was carried out by inserting blood samples to be tested into the capillary tube in $4 / 5$ parts while the tip of the micro capillary tube was blocked with crest seal. The capillary tube was then centrifuged for \pm 5 minutes at a speed of 12,000 rpm to form a layer of blood plasma, a gray-white layer (platelets and WBCs) and a red layer (RBCs). The value of PCV was determined by measuring the percentage of PCV volume using a micro hematocrit reader expressed as a percentage of the volume of the whole blood (Samour, 2015). Testing of blood hemoglobin levels was done by adding a solution containing potassium cyanide and potassium ferisianide (Drabkin's reagent) into the blood to be measured. Ferisianida will change the iron from hemoglobin, which has valence two (ferro) to valence three (ferri) to form methemoglobin. The intensity of the color of the mixture was measured using a spectrophotometer at a wavelength of $540 \mathrm{~nm}$, and transmittance reading expressed as $\mathrm{Hb} \mathrm{g} / \mathrm{dL}$ (Samour, 2015).

The calculation of the total number of red blood cells was used to calculate the average volume of blood cells (MCV) and the average hemoglobin of white blood cells (MCH). Calculation of total red blood cells (Erythrocytes) was performed using a hemocytometer of Improved Neubauer counting chamber (Samour, 2015). Blood was sucked up to 0.5 using an aspirator on an erythrocyte pipette then Rees \& Ecker solutions up to number 101 are listed on the pipette. The mixture was homogeneous with movement number 8 while covering both ends of the pipette with thumb and forefinger. A drop of liquid was put into the Improved Neubauer counting chamber. The red blood cell counts were carried out in 5 out of 25 boxes (each of which has 16 small boxes in it), namely in four boxes in the corners and one box in the Centre. The total number of red blood cells was $\mathrm{N} \mathrm{x} 10,000 / \mathrm{mm}^{3} ; \mathrm{N}=$ number of cells counted in five boxes. The next analysis was the total white blood cell count (WBCs), and to determine the differential white blood cell count; eosinophils, heterophils, basophils, lymphocytes, monocytes and platelets. To calculate the total leukocyte count was done similar to for the calculation for the total red blood cell 
count, the difference being the micropipette, the solvent, and the position of the box counter in the Improved Neubauer hemocytometer. Calculation of the total number of white blood cells was done by counting the number of cells contained in four groups of boxes in the corner of the room. The total number of red blood cells was $\mathrm{N} \mathrm{x}$ $50 / \mathrm{mm}^{3} ; \mathrm{N}=$ number of cells counted in four groups of boxes in the corner of the room (Samour, 2015).

Calculations of erythrocyte indices consist of mean corpuscular volume (MCV), mean corpuscular hemoglobin $(\mathrm{MCH})$, and mean corpuscular hemoglobin concentration (MCHC). Mean corpuscular volume is an expression of the average volume of individual erythrocytes calculated by the formula: $\mathrm{MCV}=(\mathrm{PCV} \times 10) / \mathrm{RBCs}=\mathrm{MCV}$ femto liters (fl). Mean corpuscular hemoglobin is an expression of the average hemoglobin content of a single erythrocyte calculated by the formula: $\mathrm{MCH}=(\mathrm{Hb} \times 10) / \mathrm{RBCs}=\mathrm{MCH}$ picogram $(\mathrm{pg})$. Mean corpuscle hemoglobin concentration is the expression of the volume in erythrocytes occupied by hemoglobin, and it is calculated by the formula: $\mathrm{MCHC}=(\mathrm{Hb} \times 100) / \mathrm{PCV}=\mathrm{MCHC}(\mathrm{g} / \mathrm{L})$. After the calculation of total white blood cells (WBCs) used Improved Neubauer hemocytometer, the next step was followed by leukocyte differential counts from observations of stained blood films made from blood film preparations that were fixed and stained with Giemsa-Wright stain (Samour, 2015).

All tested parameters were analyzed as a completely randomized design by one-way ANOVA using the GLM procedure (SAS, 2009), and differences among treatment means were determined using the Duncan's multiple range test.

\section{Results}

The results of some hematological parameters are illustrated in Figure 1,2, and 3 for the chickens in period I and II. Figure 1 shows the value of PCV and total count of red blood cells $(\mathrm{RBCs}=$ erythrocytes $)$ in period I (PVC I = PCV in period I and Erythrocytes I = erythrocites in period I) and in period II (PVC I = PCV in period II and Erythrocytes II = erythrocites in period II). In period I, PVC of the chickens fed diet supplemented with $0.75 \%$ curcumin $(\mathrm{Cl}=38.63)$ was significantly higher $(\mathrm{P}<0.05)$ than the chickens fed the control diets $(\mathrm{T} 01=34.38 \%$ and $\mathrm{T} 02=34.75 \%$ ), but no significant differences of PVC ware observed for the other treatments. In period II, the PCV was significantly increased $(\mathrm{P}<0.05)$ in the chickens fed diet supplemented with $1.50 \%$ curcumin $(\mathrm{C} 3=37.88 \%)$ compared to the chickens fed the control diet $(\mathrm{T} 01=34.64 \%)$, but no significant differences of PVC ware observed for other treatments. Furthermore, the RBCs of the chickens fed diet supplemented with $0.75 \%$ of ginger $(\mathrm{Z} 1=3.42$ $\left.\times 10^{6} / \mu \mathrm{L}\right)$ was significantly higher $(\mathrm{P}<0.05)$ than the chickens fed the control diet $\left(\mathrm{T} 01=2.52 \times 10^{6} / \mu \mathrm{L}\right)$. However, no significant differences $(\mathrm{P}>0.05)$ on RBC counts were observed among the treatments in Period II.

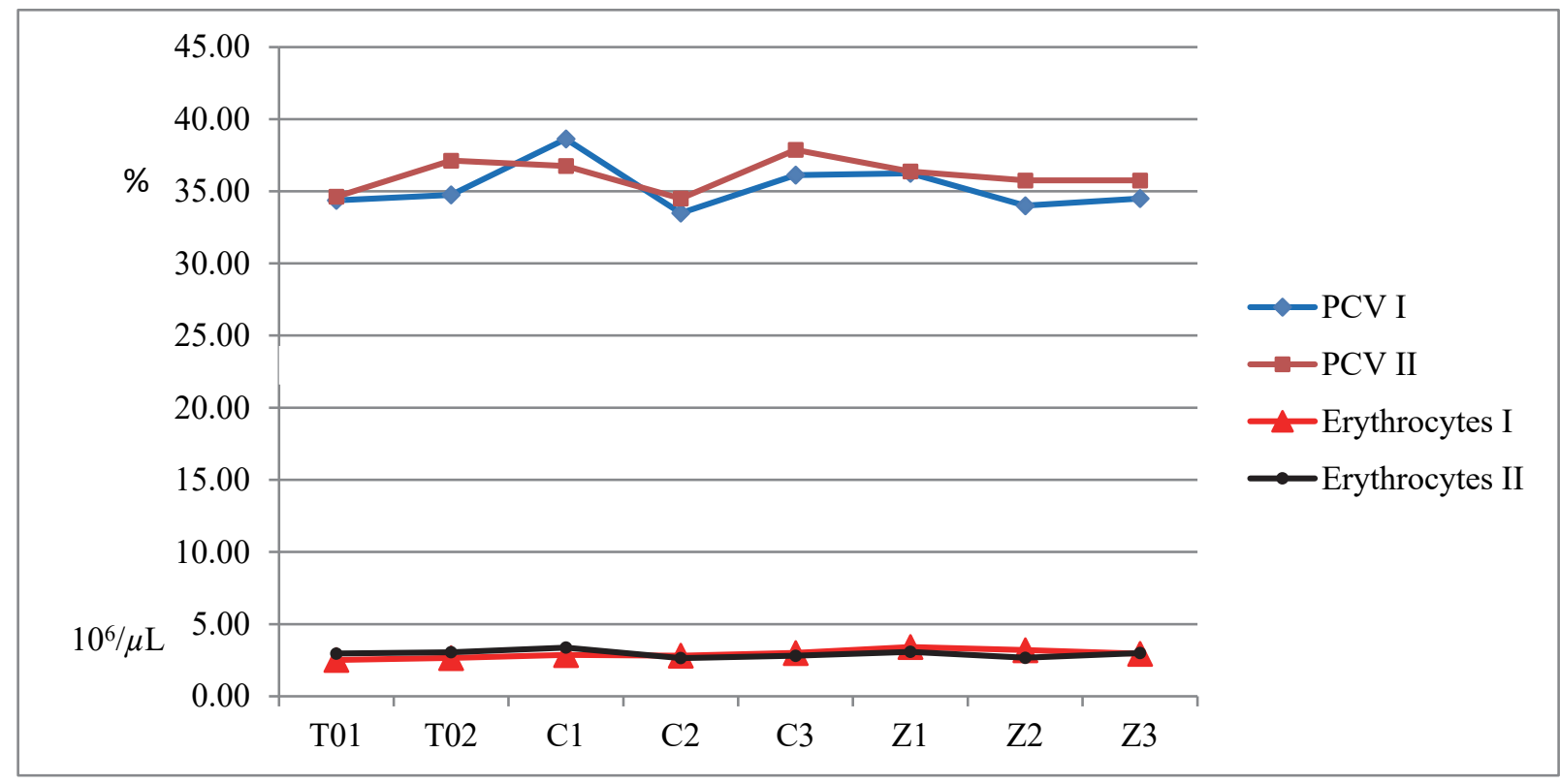

Figure 1. PCV and RBCs (erythrocytes) in period I and II

The results illustrated in Figure 2 show that no significant differences of $\mathrm{Hb}$ concentration were observed in period $\mathrm{I}$, with a range of $12.34-10.39 \mathrm{~g} / \mathrm{dL}$. However, $\mathrm{Hb}$ concentration of $\mathrm{C} 3(12.10 \mathrm{~g} / \mathrm{dL})$ increased significantly $(\mathrm{P}<0.05)$ in chickens supplanted with $1.0 \%$ curcumin compared with the Hb level of T01 control group (T01=10.28 g/dL) 
in period II. The results show that the treatments had no effect on MCHC in both period I and II, and the interval $\mathrm{MCHC}$ in period I was $34.83-28.75 \mathrm{~g} / \mathrm{dL}$, and in period II was $32.34-28-31 \mathrm{~g} / \mathrm{dL}$.

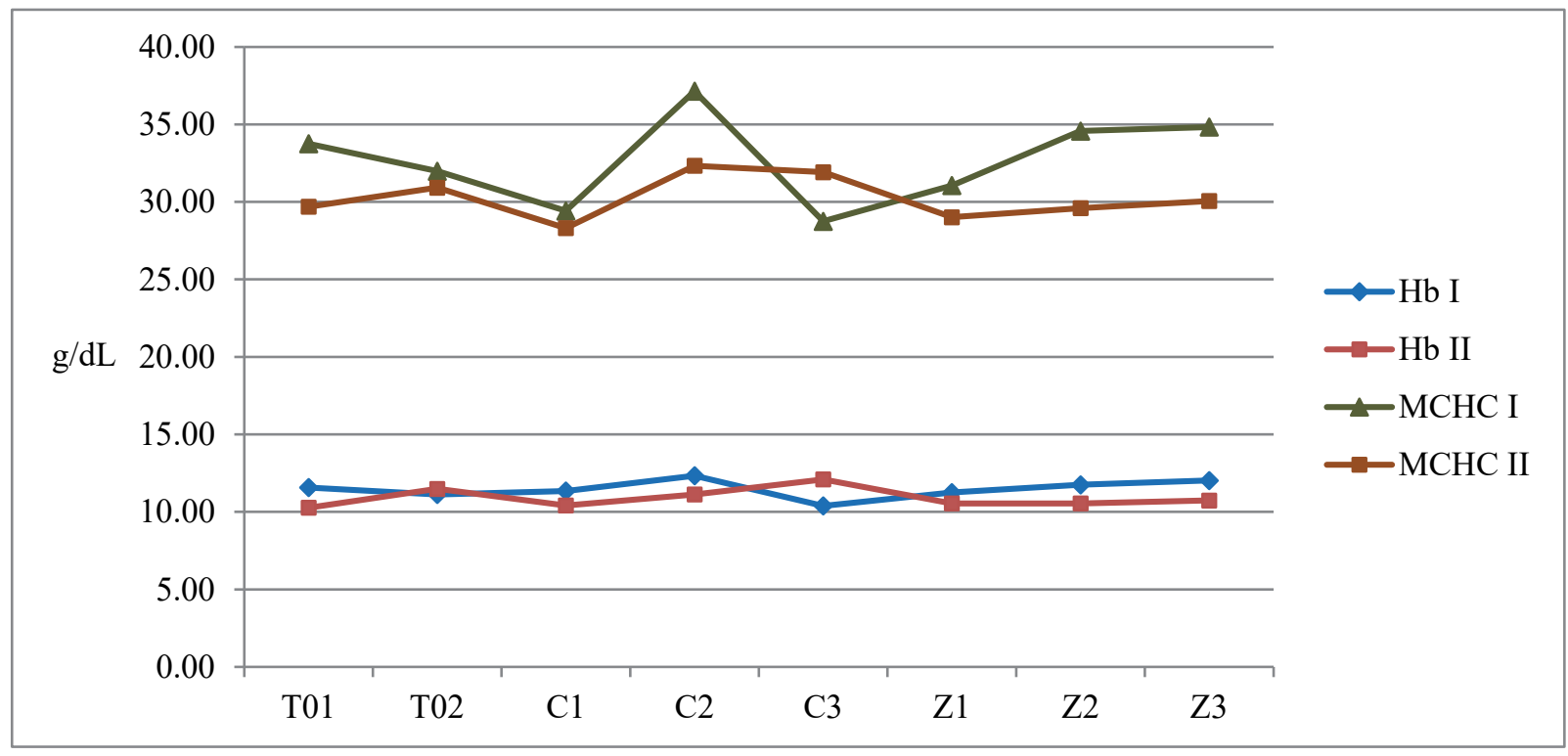

Figure 2. Hemoglobin ( $\mathrm{Hb})$ and $\mathrm{MCHC}$ in period I and II

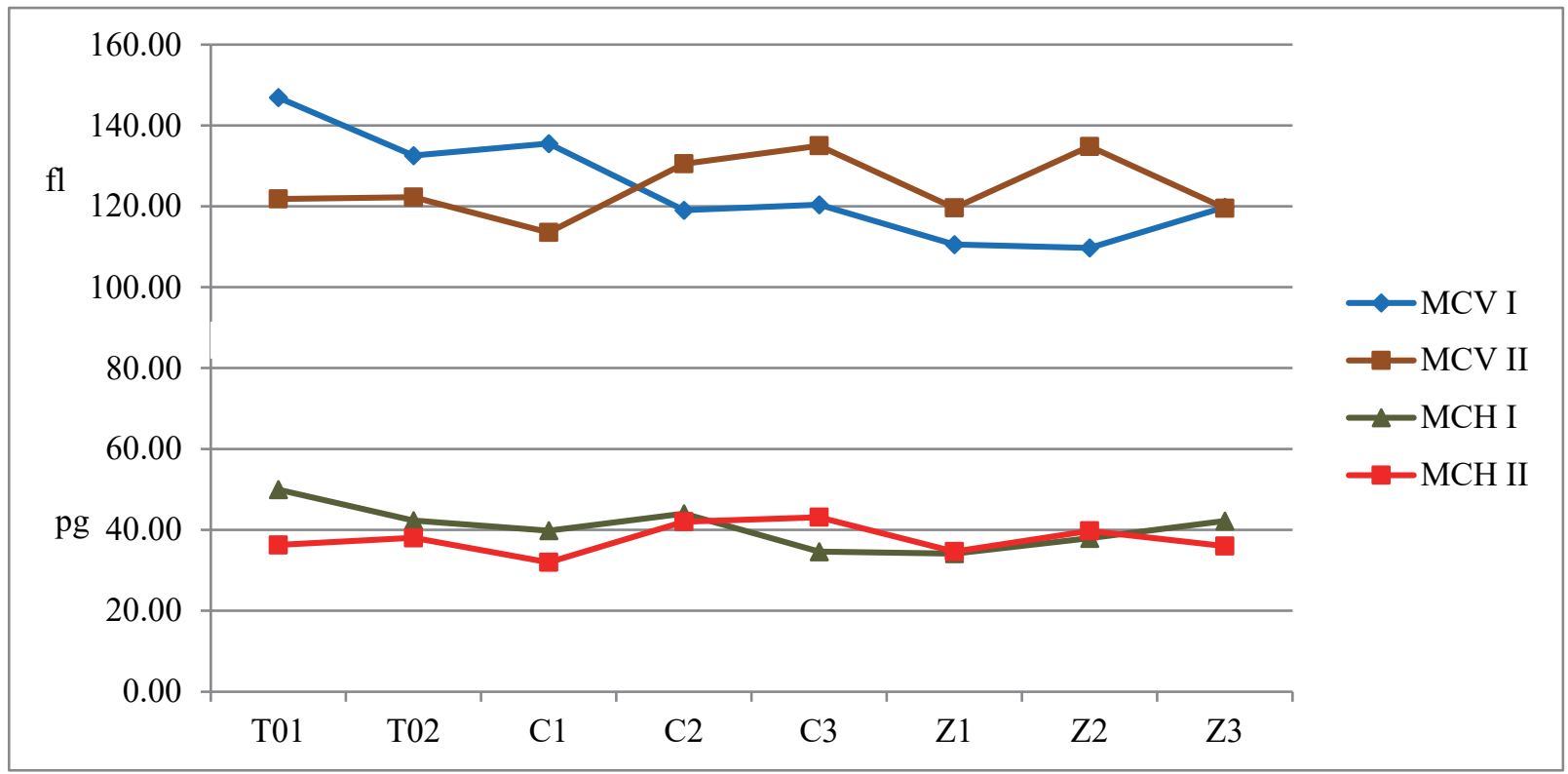

Figure 3. $\mathrm{MCH}$ and $\mathrm{MCHC}$ in period I and II

Figure 3 shows the parameters of Mean Corpuscular Volume (MCV) and Mean Corpuscular Hemoglobin (MCH). In the period II and I, no significant differences on MCVs were observed among treatments $(\mathrm{P}>0.05)$, and the interval value of $\mathrm{MCV}$ in period I was 146.90-109.79 fl, and in period II was 135.01-113.54 fl. In contrast to the $\mathrm{MCV}$, dietary inclusion of the addition $1.5 \%(\mathrm{C} 3=34.61 \mathrm{pg})$ and $0.75 \%(\mathrm{C} 1=34.16 \mathrm{pg})$ ginger significantly decreased $(\mathrm{P}<0.05) \mathrm{MCH}$ compared to control group (T01=49.94) in period $\mathrm{I}$, but no significant differences on $\mathrm{MCH}(\mathrm{P}>0.05)$ ware observed in period II. 
The WBC counts and differential leukocyte count in period II are presented in Table 1. Results revealed that the chickens fed diet containing $1.5 \%$ curcumin $(C 3=17.82)$ had significantly lower WBCs compared with control group $\left(\mathrm{T} 01=25.97 \times 10^{3} / \mu \mathrm{L}\right)$. However, no significant differences were investigated in the percentage of eosinophil and basophil $(\mathrm{P}>0.05)$. The highest percentage of heterophils was observed for $\mathrm{C} 3(29.90 \%)$ and significantly increased $(\mathrm{P}<0.05)$ compare to control of T02 $(27.42 \%)$, but the heterophil decreased significantly $(\mathrm{P}<0.05)$ in chickens of Z3 (24.85\%) compare with control of T01 (28.21\%). Furthermore, the percentage of lymphocytes of broilers was increased $(\mathrm{P}<0.05)$ by Z3 treatment $(64.26 \%)$ compare to T02 control $(57.90 \%)$, and treatment with $1.0 \%$ of ginger $(9.95 \%)$ decreased monocyte counts $(\mathrm{P}<0.05)$ compared to the T02 control $9.44 \%)$. Finally, Results revealed that birds fed diet containing $1.5 \%$ of ginger had significantly lower heterophils: lymphocytes $(\mathrm{H} / \mathrm{L})$ ratio compared with T02 control $(\mathrm{P}<0.05)$. Although there were differences among the leukocyte differential counts, they are still in the interval reference values (Thrall et al., 2012; Table 1).

Table 1. The total WBC count and the total differential leukocyte count of the chickens at the end of period II)

\begin{tabular}{|c|c|c|c|c|c|c|c|}
\hline & WBCs & Eosinophils & Heterophils & Basophils & Lymphocytes & Monocytes & Heterophils/ \\
\hline Treatment & $\left(\mathrm{x} 10^{3} / \mu \mathrm{L}\right)$ & $\%$ & $\%$ & $\%$ & $\%$ & $\%$ & Lymphocytes \\
\hline T01 & $25.97^{\mathrm{a}}$ & 3.29 & $28.21^{\mathrm{ab}}$ & 0.49 & $62.68^{a b c}$ & $5.32^{c}$ & $0.45^{a b c}$ \\
\hline T02 & $23.54^{\mathrm{ab}}$ & 4.02 & $27.42 \mathrm{bc}$ & 1.23 & $57.90^{d}$ & $9.44^{\mathrm{a}}$ & $0.47^{\mathrm{ab}}$ \\
\hline $\mathrm{C} 1$ & $18.26^{\mathrm{ab}}$ & 2.85 & $26.42 \mathrm{bc}$ & 0.84 & $63.00^{\mathrm{ab}}$ & $6.89 \mathrm{bc}$ & $0.42^{b c}$ \\
\hline $\mathrm{C} 2$ & $23.34^{\mathrm{ab}}$ & 3.71 & $26.24^{b c}$ & 0.55 & $62.69^{a b c}$ & $6.81^{b c}$ & $0.42^{b c}$ \\
\hline $\mathrm{C} 3$ & $17.82^{b}$ & 3.01 & $29.90^{\mathrm{a}}$ & 0.70 & $58.84^{\mathrm{cd}}$ & $7.55^{a b c}$ & $0.51^{\mathrm{a}}$ \\
\hline $\mathrm{Z1}$ & $22.46^{\mathrm{ab}}$ & 4.01 & $26.71^{a b c}$ & 0.74 & $61.83^{a b c}$ & $6.72^{b c}$ & $0.43^{b c}$ \\
\hline $\mathrm{Z2}$ & $24.07^{\mathrm{ab}}$ & 4.50 & $26.06^{b c}$ & 0.51 & $62.98^{a b}$ & $5.95^{c}$ & $0.41^{b c}$ \\
\hline $\mathrm{Z3}$ & $21.20^{\mathrm{ab}}$ & 3.89 & $24.85^{\mathrm{c}}$ & 0.68 & $64.26^{\mathrm{a}}$ & $6.33^{b c}$ & $0.39^{\mathrm{c}}$ \\
\hline Reference interval $^{\mathrm{d}}$ & & $0-16$ & $15-50$ & $0-8$ & $29-84$ & $0-7$ & $0.52-0.60$ \\
\hline
\end{tabular}

${ }^{\text {a-c }}$ Means not sharing the same superscript letter within each column differ at $\mathrm{P}<0.05$.

d Thrall et al. (2012)

\section{Discussion}

The results of this study indicated that supplementations of ginger and curcumin up to a dose of $1.5 \% / \mathrm{kg}$ of diets have improved in several hematological parameters, such as PVC, RBCs, and $\mathrm{Hb}$. The results showed that the intervals of PCV were $38.63-33.5 \%$ in period I, and 37.88-34.5\% in period II. When compared with the interval reference value (23-55\%) from Campbell and Grant (2010), the packed cell volume of the chickens was in the interval reference. Therefore, the diets supplemented with curcumin and ginger of this study may be considered useful as a preventive measure against ascites, since the packed cell volume is an indicator for ascites as a natural physiological response in birds. Moreover, the interval of the total red blood cell counts in period I and II was (2.52-3.38 $\left.\times 10^{6} \mu \mathrm{L}\right)$, with an average RBCs of $2.95 \times 10^{6} / \mu \mathrm{L}$. Thus, the interval of erythrocyte counts was still in the reference interval of 2.50-3.50 x $10^{6} \mu \mathrm{L}$ (Weiss \& Wardrop, 2010), and the overall Hb levels were still in the normal interval of 7-13 g/dL. Moreover, the interval value of MCHC (31.92-28.31 g/dL) and the interval value of MCV (109.79-46.90 fl) were still in the interval references of 35-26 g/dL and 140-90 fl, respectively. However, the MCH intervals in period I (49.95-34.16 pg) and in period II (56.83-41.83 pg) were higher compared with MCH interval reference (47.00-33.00 pg; 2010).

The results of the study were in line with several previous studies. Research by administering ginger by oral infusion at a dose of $100 \mathrm{mg} / \mathrm{kg}$ body weight for 6 weeks showed a significant increase $(\mathrm{P}<0.05)$ in hemoglobin and PCV concentrations compared with controls (AL-Moramadhi, 2010). Other studies have also shown that administration of ginger in doses of $200 \mathrm{mg} / \mathrm{kg}$ of feed provides hematological data that has implications for significant increases in PCV and hemoglobin, and the total number of total leukocyte count and percent heterophils in doses of $100 \mathrm{mg} / \mathrm{kg}$ of feed have also shown an increase. This means that immunologically, there was a significant increase in phagocytic activity of heterophils and antibody titers against several types of viral diseases at a dose of $100 \mathrm{mg} / \mathrm{kg}$ of feed (Saleh et al., 2014). The results of research conducted by Zomrawi et al. (2012) have proven that the addition of ginger powder at the level of $0.5 \%$ and $1.0 \%$ in feed can improve its performance and hematology parameters, and chicken can still tolerate the addition of up to $1.5 \%$ without affecting the measured parameters. However, treatment with the addition of ginger flour at a dose of $2.0 \%$ in broiler feed by Zomrawi et al. (2012) showed differences in $\mathrm{Hb}, \mathrm{PCV}$, total RBCs, percentage of MCHC, and a decrease in MCH compared 
with the control treatment. The results of previous studies also showed that the $0.5 \%$ dose of curcumin addition had shown an increase in $\mathrm{Hb}$, total RBCs, and PVC, but on further addition to a dose of $1.0 \%$ curcumin there was an increase in the number of white blood cells (Al-Noori et al., 2011). Furthermore, the study of Belal et al. (2018) showed that chickens receiving $1.5 \% / \mathrm{kg}$ feed of ginger in powder form in feed showed significant increases in $\mathrm{Hb}$ ( 7.33 to $8.66 \mathrm{~g} / \mathrm{dL}$ ) and MCHC (27.67 to $29.45 \%$ ). However, studies with a dose of $0.6 \%$ ginger powder did not have the potential to be used as growth promoters in broiler chicks. The results of this study showed that there were no significant differences in the hematological values and serum biochemical parameters between the treatment groups (Hassan et al., 2019).

In contrast to the results of previous studies, the results of Amaduruonye et al. (2020) showed that the addition of ginger at doses up to $3.0 \%$ did not give a difference in effect on all haematological parameters observed, but did not have a detrimental effect on these haematological parameters. However, the results of this study indicate that supplementation of ginger root flour above $1.5 \%$ in the poultry diet can adversely affect the histopathological examination of the internal organs of broilers. An experiment using high doses of ginger by Ebegbulem (2018) was carried out to determine the effect of feeding ginger levels up to $8.0 \%$ on hematology and serum biochemical indices in broilers. The results showed that all hematological indices of birds were not significantly affected by these treatments. This study concludes that ginger can be added up to $6 \%$ in broiler chicken food without reducing its physiological status. On the contrary, supplementation of feed with ginger up to $1 \%$ has been able to increase body weight and hematological parameters as well as the chemical components of chicken blood (Isidahomen, 2016).

The values of H/L from blood analysis can be used as an indicator of stress (Al-Daraji and Salih, 2012) and can be used as reliable biomarkers that indicate any inflammations stimulated by feed-induced stress (Disetlhe et al., 2018). The normal interval of $\mathrm{H} / \mathrm{L}$ ratio according to Thrall et al. (2012) is $0.52-0.6$, but $\mathrm{H} / \mathrm{L}$ value of the research done by Al-Daradji and Salih (2012) was in the interval of 0.6-1.2. The high value within the range shows that animal are under stress, which if it lasts long means the animal has experienced an acute condition and $\mathrm{H} / \mathrm{L}$ above 1.3 the chicken has turned into sick. Therefore, the ratio of $\mathrm{H} / \mathrm{L}$ can be used as an indicator of the long-term reaction of livestock to the environment. However, another study showed that application of the H/L method alone is inadequate (Cotter, 2015). Measurement of $\mathrm{H} / \mathrm{L}$ could be combined with measurement of blood corticoid hormone as a form of short-term reaction of livestock to the environment. In this, study the value of the $\mathrm{H} / \mathrm{L}$ ratio was in the interval of 0.39-0.51, including the treatment control, so the chickens were said to be in a non-stress condition. In general, hematology indices usually indicate the health status of animals. Although, there was a decrease in the count of white blood cells in the treatment with addition of curcumin, compared to the WBC counts based on Weiss and Windrop (2010) being in the interval of 12.0-30.0 x $10^{3} / \mu \mathrm{L}$, the results of this study were still in the interval of the references. Moreover, diet supplemented with $1.5 \%$ ginger $(\mathrm{Z} 3=0.39)$ decreased $\mathrm{H} / \mathrm{L}$ ratio of the chickens $(\mathrm{P}<0.05)$ compared to the control group $(\mathrm{T} 02=0.47)$. These results indicated that diets supplemented with curcumin and ginger up to $1.5 \%$ had potencials in improving the general health status of broilers.

\section{Conclusion and Recommendation}

Conclusion: The use of curcumin and zingiber medicinal plants has been proven to improve hematological parameters from the results of this study, and some previous studies showed not only improving on hematological value but also on immune system. These improvements are supported by heterophils/lymphocyte ratio data on the addition of herbal plants curcumin and zingiber that have decreased significantly. These conditions indicate that the addition of medicinal plants of curcumin and ginger in broiler chicken diets can improve the hematological values and reduce stress levels of the chicken.

Recommendation: The Indonesian government should be able to improve policies that have been taken to prohibit the total use of synthetic antibiotics. The recommendation aims to be able to encourage the use of medicinal plants in farmers as supplemented feed for especially preventing diseases. Furthermore, the use of medicinal plants will avoid cases of residue and resistance due to the use of uncontrolled synthetic antibiotics and will produce an environmentally friendly livestock system because the plants can utilize abundant natural products and low prices because they are easily cultivated. Finally, we urge the government to prohibit strictly the use of synthetic antibiotics completely and instead the government should use medicinal plants primarily for preventing disease.

\section{Acknowledgment}

The authors gratefully acknowledge the supporting fund of Indonesian Institute of Science (LIPI), Ministry of Research and Technology for this research conducted. The helful students and animal keepers of the Fapet farm, Jambi University are acknowledged for their assistance in performing the study. 


\section{References}

Al-Daraji H., \& Salih, M. (2012). The influence of the dietary arginin supplementation on blood traits of broiler chickens. Pakistan Journal of Nutrition, 11(3), 258-264. Retrieved from https://scialert.net/abstract/?doi=pjn.2012.258.264

Al-Jaleel, R. A. A. (2012). Use of turmeric (Curcuma longa) on the performance and some physiological traits on the broiler diets. The Iraqi Journal Veterinary Medicine, 36(1), 51-57. Retrieved from https://ijvm.iraqjournals.com/article_51423_a5b42b2e0e6b0005c678a6fa7a60d70a.pdf

Al-Moramadhi, S. A. H. (2010). The Effect of Zingiber officinale roots infusion on some physiological parameters in broiler chickens. Kufa Journal for Veterinary Medical Science, 1(2), 67-76. Retrieved from https://www.iasj.net/iasj?func=fulltext\&aId=32860

Al-Noori, M. A., Hossain, A. B., AL-Maahidy, A. H. A., \& A-Rawi, S. T. J. (2011). The Effect of dietary Curcuma Longa powder (turmeric) supplementation on some blood parameters and Carcass Traits of Broiler Chickens. Al-Anbar Journal of Veterinary Science, 4(Supplement, 69-74. Retrieved from https://scholar.google.com/citations?user=WLnrXjMAAAAJ\&hl=ar

Amaduruonye, W., K. Ikwunze, Oguike, M. A., \& Onunkwo, D. N. (2020). Influence of ginger (Zingiber officinale) on histology, blood profile and internal organ characteristics of broilers. Nigerian Journal of Animal Science, 20(1), 61-71. Retrieved from https://www.researchgate.net/publication/341454026_Influence_of_ginger_Zingiber_officinale_on_histolo gy_blood_profile_and_internal_organ_characteristics_of_broilers

Belal, S. A., Uddin, M. N., Hasan, M. K., Islam, M. S., \& Islam, M. A. (2018). Effect of ginger (Zingiber officinale) and garlic (Allium sativum) on productive performance and hematological parameters of broiler. EPHInternational Journal of Agriculture and Environmental Research, 4(1), 12-23. Retrieved from https://www.ephjournal.org/index.php/aer/article/view/470

Campbell, T. W., \& Grant, K. R. (2010). Clinical Cases in Avian and Exotic Animal Hematology and Cytology. Willey-Blackwell, A. John Wiley \& Sons Ltd, Publication

Disetlhe, A. R. P., Marume, U., \& Mlambo, V. (2018). Humic acid and enzymes inclusion in canola-based diets generate different responses in growth performance, protein utilization dynamics, and hemato-biochemical parameters in broiler chickens. Poultry Science, 97, 2745-2753. http://dx.doi.org/10.3382/ps/pey047

Ebegbulem, V. N. (2018). Haematological and biochemical indices of broiler chickens fed ginger (Zingiber officinale) based diets. Ife Journal of Agriculture, 30(2), 1-7. Retrieved from https://ephjournal.org/index.php/aer/issue/view/154

Hassan, R. I., Mosaad, G. M., \& Abd El-Wahab, H. Y. (2019). Effect of Dietary Supplemental Ginger on Broiler Performance, Carcass Characteristics and Blood Profile. SVU - International Journal of Veterinary Sciences, 2(1), 108-118. Retrieved from https://svu.journals.ekb.eg/article_28977.html

Isidahomen, C. E. (2016). Effect of diets containing supplements of ginger (Zingiber officinale) and vitamin C on body weight, haematology and blood serum components in cocks. Nigerian Journal of Agriculture, Food and Environment, 12(2), 162-165. Retrieved from http://njafe.com/njafe2016v12n2/28Isidahomen.pdf

Isroli, I., Yudiarti, T., Widiastuti, E., \& Sugiharto, S. (2017). Effect of decocted turmeric on performance, hematological parameters and carcass traits of broiler chickens. Journal of the Indonesian Tropical Animal Agriculture, 42(2), 263-269. http://eprints.undip.ac.id/64764/

Kusnadi, E., \& Rachmat, A. (2010). The effect of turmeric (Curcuma domesticaval) supplementation on changes in blood components and growth of broiler indicated heat stress. National Seminar on Animal Husbandry and Veterinary Technology, 761-765. Retrieved from https://docplayer.info/31493305-Seminar-nasionalteknologi-peternakan-dan-veteriner-2010.html

Liu, M., Lu, Y., Gao, P., Xie, X., Li, D., Yu, D., \& Yu, M. (2020). Effect of curcumin on laying performance, egg quality, endocrine hormones, and immune activity in heat-stressed hens. Poultry Science, 99, $2196-2202$. https://doi.org/10.1016/j.psj.2019.12.001

NRC. (1994). Nutrient Requirements of Poultry. $9^{\text {th. }}$ Revision Edition. National Academic Press, Washington, D.C.

Rahmawati, E. (2018). Regulation of the Minister of Agriculture No. 14 year 2017 concerning Veterinary Drug Classification. Directorate General of Animal Husbandry and Animal Health, Indonesian Ministry of Agriculture. 
https://pdfs.semanticscholar.org/029e/feac3bba1c7db6f2e14fa5ad57e455f7ad88.pdf

Saefudin, S. P., Trisawa, I. M., Wulandari, S., Sulasteri, S., \& Yuniyati, N. (2016). Herbs Based Medical Plants for Livestock. Indonesian Center for Estate Crops Research and Development, Indonesian Ministry of Agriculture.

Saleh, N., Allam, T., El-Latif, A. A., \& Ghazy, E. (2014). The Effects of Dietary Supplementation of Different Levels of Thyme (Thymus vulgaris) and Ginger (Zingiber officinale) Essential Oils on Performance, Hematological, Biochemical and Immunological Parameters of Broiler Chickens. Global Veterinarian, 12(6), 736-744.

Samour J. (2015). Diagnostic Value of Hematology in Clinical Avian Medicine. Volume II. Harrison GJ, Lightfoot TL. Spix Publishing, Florida.

SAS. (2009). SAS/STAT ${ }^{\circledR}$ 9.2. User's Guide. SAS Institute Inc. Cary, North Carolina.

Smith, J. A. (2011). Experiences with drug-free broiler production. Poultry Science, 90, 2670-2678. Retrieved from

https://reader.elsevier.com/reader/sd/pii/S0032579119423328?token=62E2A35172077ECFC64AA2CF00C 39459FB01830094A3C39CEB1FA95B4B106582197ACC82C24E4133D5E2A482EF568EA8

Thrall, M. A., Weiser, G., Allison, R. W., \& Campbell, T. W. (2012). Veterinary Hematology and Clinical Chemistry (2nd Ed). John Willey \& Sons, Inc.

Weiss, D. J., \& K. J. Wardrop. (2010). Schalm's Veterinary Hematology (6th Ed). Blackwell Publishing Ltd.

Zomrawi, W. B., Abdel K. H. A., Atti, Dousa, B. M., \& Mahala, A. G. (2012). The effects of ginger root powder (Zingiber officinale) supplementation on broiler chick performance, blood and serum constituents. Online Journal of Animal and Feed Research, 1(6), 457-460. Retrieved from http://41.67.20.41/bitstream/handle/123456789/22871/8.pdf?sequence=1\&isAllowed=y

\section{Copyrights}

Copyright for this article is retained by the author(s), with first publication rights granted to the journal.

This is an open-access article distributed under the terms and conditions of the Creative Commons Attribution license (http://creativecommons.org/licenses/by/4.0/). 